\title{
38. Aşın kutu yahut kutsuz aş
}

\section{Muhammet ATASEVER'}

\begin{abstract}
APA: Atasever, M. (2021). Aşın kutu yahut kutsuz aş. RumeliDE Dil ve Edebiyat Araştırmaları
\end{abstract} Dergisi, (23), 594-606. DOI: 10.29000/rumelide.949499.

\section{$\ddot{O} \mathbf{z}$}

Tarihi, coğrafi, dini ve sosyolojik sebeplerden Türk ailesi, kadın egemen yapıdan ataerkilliğe ve sonrasında eşitlikçi aileye doğru üç farklı kültürel geçiş aşaması takip eder. Her bir aile tipi kendine haiz özelliklere sahiptir ve toplumsal cinsiyet de buna göre şekillenir. Ailede otoritenin tekilliği ya da bölünmüşlüğü, kadın-erkek arasındaki görev dağılımında değişiklikleri beraberinde getirse dahi; kadın, toplumun kendisine verdiği birçok vazifesi ile birlikte doyurmak görevini daima üstlenir ve bu yükümlülük hemen hiçbir değişikliğe uğramadan günümüze kadar intikal eder. Türklerde aş yahut aş verme toplumbilimsel mana ve bağlamda çok yönlü bir eylemdir. Yemeğin hazırlık evresi, boş vakit kavramına yabancı olan Türk kadınının bir araya geldiği, sohbetler ettiği, işi ve aşı kolaylaştırdığı sosyalleşme alanlarından birisidir. Söz konusu buluşmalar bilgi alışverişinin yapıldığı, yeni nesillere birikimlerin, Türkün örf ve adetinin aktarıldığı okullardır. Kadın burada toplumsallaşırken geleneğin icrası ve sonraki kuşaklara nakli konusunda önemli bir görev ifa eder. Böylelikle kadının örtük veya açık bu eğitimi, yalnızca tekil bir eylem olmaktan çıkar ve kültürün yaratıldığı, yaşatıldığı bir fiile dönüşür. Çalışmada, toplumun eril ve dişil fertlere taksim edilen ödevler neticesinde, ocak ve etrafında teşekkül eden vazifelerin kadına yüklendiği, görev dağılımının Türk kültüründe yer alan kız çocuğun erkek çocuktan değersiz, arka plânda veya farklı konumda düşünülüp görülmesi ile ilişkisi, toplumsal cinsiyet bağlamında kadın ve erkeğin sofradaki rolü üzerinde durulmuştur. Türkün konukseverliği bilhassa Dîvânu Lugâti’t-Türk’ten konu bağlamında verilen örneklerle gösterilmiş, aş ve aşın siyasi, sosyal ve ekonomik fonksiyonu değerlendirilmiş, Türk tefekkürüne göre uğur ve bereketine inanılan aşın, Barak Ovası'nı yurt tutan Çarganlı Türkmenleri arasında, kadın eli ile kutsuz aşa ve akabinde bir halk inanmasına nasıl dönüştüğüne değinilmiştir.

Anahtar kelimeler: Barak Ovası, Türkmenler, toplumsal cinsiyet, kadın, aş/yemek, kut

\section{Ritual of food or food without ritual}

\begin{abstract}
The Turkish family follows three different stages of cultural transition from a woman-dominated structure to patriarchy and then to an egalitarian family due to multifarious historical, geographical, religious, and sociological reasons. Each family type has its own characteristics and gender is shaped accordingly. Even if the singularity or division of authority in the family leads to changes in the distribution of duties between men and women, the woman always assumes the duty of feeding, along with the many duties assigned to her by the society, and this obligation has been transferred to present-day without any change. Food or organizing feasts in Turkic societies is a multi-faceted event in sociological meaning and context. The preparation phase of the feast is one of the
\end{abstract}

Öğr. Gör. Dr., Kilis 7 Aralık Üniversitesi, Rektörlük, Türk Dili Bölümü (Kilis, Türkiye), atasevermuhammet@gmail.com, ORCID ID: 0000-0002-9633-8297 [Araştırma makalesi, Makale kayıt tarihi: 17.03.2021-kabul tarihi: 20.06.2021; DOI: 10.29000/rumelide.949499]

RumeliDE Dil ve Edebiyat Araşttrmaları Dergisi Osmanağa Mahallesi, Mürver Çiçeği Sokak, No:14/8 Kadıköy - İSTANBUL / TÜRKIYE 34714 e-posta: editor@rumelide.com tel: +90 505 7958124, +90 2167730616
Address

RumeliDE Journal of Language and Literature Studies

Osmanağa Mahallesi, Mürver Çiçeği Sokak, No:14/8

Kadıköy - ISTANBUL / TURKEY 34714

e-mail: editor@rumelide.com,

phone: +90 $5057958124,+902167730616$ 
socializing areas where Turkish women, who are not familiar with the concept of leisure time in a secular sense, come together, have conversations, and facilitate the work. These gatherings are schools where information is exchanged, knowledge and customs of Turks are passed on to new generations. While the woman here is socialized here, she fulfills an important duty in the execution of tradition and its transfer to the next generations. Thus, the implicit or explicit education of women ceases to be just a singular act but turns into an act in which culture is created and sustained. This study focuses on the elements in which the duties in the hearth and its surroundings are attributed to the woman, girls are considered inferior or in worthless position compared to boys in the distribution of the tasks, and the role of man and woman at the table is considered. The hospitality of the Turkish people is highlighted with examples form Divanu Lugâti't-Türk; political, social and economic function of food is evaluated, and how food, believed to be fortune and blessing, was turned into a ritualistic feast and folk belief with the touch woman's hand among Tsargani Turkmens in Barak Plains.

Keywords: Barak Plain, Turkmens, gender, woman, food, ritual

\section{Giriş}

Yemek, toplumbilimsel, ruhbilimsel, dinsel, sanatsal ve tarihi boyutlara sahip, toplumu yansitan ve onun coğrafyasını ele veren bir olgudur. Aş, yalnızca hazırlanan ve sonrasında tüketilen bir gıda değildir. Yemekte kullanılan malzemeden pişirme şekillerine, yenilen ve yenmeyen gıdalara, yemeğin ikram ediliş usulüne, yemek yapmakla vazifeli kişiye, sofrada oturma düzenine, yemeğin yapıldığı ortamın şartlarına, yemek ile ilgili halk inanmalarına kadar; yemek etrafında bir kültür şekillenir ve yemek bir kimlik kazanır.

Medeni toplumların ve siyasi otoritelerin dahi beslenme üzerine geliştiği, inşa edildiği düşüncesinde olan Standage'e göre, ilkel kabilelerden günümüze kadar kadim topluluklar dini, ekonomik ve sosyal sistemleri gıda üretim ve dağıtımı temelliydi. Tarım ile başlayıp depolama, sulama sistemlerinin gelişmesi merkezi siyasi güçleri, bu da besin, ödeme ve vergi sistemini oluşturmuştur. Besin aynı zamanda iktidarın gücünü tanımlayan ve pekiştiren bir unsur haline gelmiştir (2016: s.12).

Konar-göçer Türk boylarında benzer biçimde siyasi birlikteliklerin tesisini, itaat ve güç denklemini değerlendiren Beşirli'ye göre, karizmatik otoriteye dayalı olarak tesis edilen birlikteliklerde hakanın güçlü olması ve beslemeye dayalı vasıflarını ön plânda tutması ve siyasal hiyerarşiyi koruması törensel pratiklerin önemli bir unsuru olarak ön plâna çıkmaktadır (2011: s.111). Eski Türklerde olduğu gibi Selçuklu ve Osmanlıda da yemek siyasi bir güç olarak görülmeye devam etmiştir; ancak yedirmek veya cömertlik aynı zamanda dini gayelerle de yapıldığı için İslam'ın kabulünden sonra mesele iki boyutlu bir hal almıştır. Orta Asya'daki misafirperverlik ananesinin yerini vakıflar almıştır (Közleme, 2013: s.391).

Aş ve aş vermenin otorite, güç, prestij, iktidar göstergesi olmasının yanı sıra törensel pratiklerde dini sebeplerden dolayı da önemsenmesi çă̆ımıza yansır, salt yemek için yemeyen Türkler, gelişmiş mutfakları ile dünya mutfakları içerisinde hatırı sayılır bir yere sahip olurlar. Türklerde dini ve milli günlerde, çeşitli olaylardan önce yahut sonra kutuna inandıkları için yemek verilir: doğum, sünnet, evlilik aşamaları -isteme, söz, nişan, kına, düğün- asker uğurlama ve karşılamaları, vefat ve ertesi ölünün üçü, yedisi, kırkı, sene-i devriyesi- iftar, kandil, Hıdırellez, bayram vs. Ayrıca bir felaketin vuku

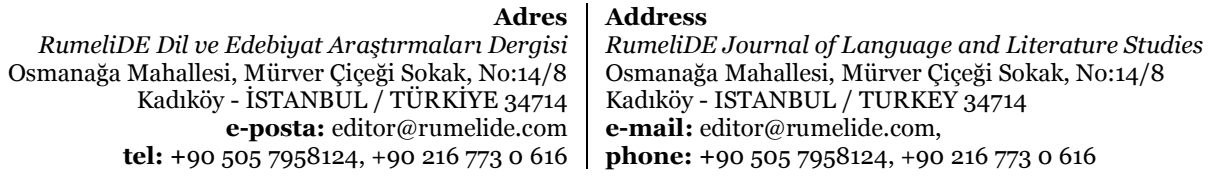

tel: +90 505 7958124, +90 2167730616 
bulması, beladan kurtulma, neslin muhafazası, sevinçli haber alma, adak adama gibi bazı hususi durumlarda da yemek verildiği olur.

Her eylem kendisinin fiile dönüştürüleceği bir mekâna ihtiyaç duyar. Türk kültüründe yalnızca bedensel bir eylem olmaktan çıkan yemeğin mekânı da ocak yahut mutfaktır. Sadece yemek hazırlanıp tüketilen bir yer olmayan bu mekânlar kendine has özellikleri ile birlikte birçok fonksiyona da sahiptir. Konu hakkında yerli ve yabancı kaynaklardan hareketle kapsamlı bilgiler veren Dinç, bu işlevleri şu başlıklar altında değerlendirir: prestij ve statü işlevi, arkadaşlık ve iletişim işlevi, hediyeleşme ve paylaşma işlevi, kutlama, ziyafet ve eğlence işlevi, ritüelistik işlev, toplumsallaşma işlevi, ailenin yüceltilmesi işlevi, turizm ve tanıtım işlevi, diğer-gizli işlevler (2021: s.306-310).

Türkün mutfak anlayışında, anaerkil sonrasında pederî aileden nihayetinde modern aileye geçiş bazı değişiklikleri² ${ }^{2}$ beraberinde getirse de aşı veren ekseriyetle erkek olsa da işin mutfağında kadın hep vardır. Bilhassa son yüzyılda kadının çalışma hayatına girmesi ile sorumluluklarının daha da artması, sosyal hayatın her yerinde nice görev ile donanması, hayatın her sahasında görülmesi, Türk ailesinde 3 kadının aşın oluşmasındaki mimarlık vasfını değiştirmez. Yuvayı yapan dişi kuştur; erine göre bağla başını, harcına göre pişir aşını; avrat var ev yapar, avrat var ev yıkar; her kadın evinin hem hanımı hem halayığıdır (Kurt, 1992: s.639) atasözleri de onun vazifelerinden bazılarını veciz bir tarzda aktarır.

Türk mutfağında aile tipleri ile meydana gelen değişimin nedenleri ise şu şekilde sıralanabilir: batı kültürünün etkisi, göç ve kentleşme, kadının çalışma yaşamına girmesi, kitle iletişim araçlarının etkisi, gıda endüstrisindeki gelişmelerin etkisi, fast food (ayak üstü beslenme), turizmin etkisi (Güler, 2007: s.22-26).

Kadın ${ }^{4}$ ocaktaki rolü ile sadece bir eylemi gerçekleştirmiş olmaz; aynı zamanda yemeğin her aşaması, onun kültürel misyonu adına kadına önemli bir alan ve zaman yaratır. İmece usulü hazırlanan toplu yemekler geleneğin aktarımı hususunda özellikle kadınlar arasında bilinçli ya da bilinçsiz biçimde hizmet verir. Öğüt Eker, temelde biyolojik ihtiyaçtan kaynaklanan yemek ve yemek kültürünün, dünya coğrafyasında kültürlere göre marjinal özellikler gösterebildiği, besin maddelerinin çeşitlerinden pişirilme şekillerine, sofra düzeninden yemek sunumuna, yemeğe ayrllan süreden dişil ve eril cinse atfedilen besin maddelerine uzanan çok geniş bir perspektifte değerlendirilmesi gerektiğini ve yaşanılan toplumun dinî, kültürel, sosyal, ekonomik ve coğrafî özellikleriyle doğrudan ilişkili kültürel değerler sistemi (Öğüt Eker, 2018: s.182) olduğuna işaret eder.

\section{Türk konukseverliği}

Arapça misafir, Türkçe konuk, Farsça mihmân (Özdemir, 1991: s.740) kelimeleri yabandan haneye gelen tanıdık yahut tanımadık herkes için kullanılır. Hatta "Tanrı misafiri” fikri, hanesi dost düşman, bildik bilmedik herkese açık Türklere has bir inançtır. Konuksever-misafirperver ise; konuğu seven, konuk ağırlamayı bir meziyet haline getirmiş insanlara denir (Özdemir, 1991: s.740).

Dîvânu Lugâti't-Türk'te konu ile alakalı kelimelerin fazlalığı, konuklarına hürmet edenlerin yüceltilmesi Türk inancında misafirin değerini ve Türk konukseverliğini gösterir bir vesikadır. Yemek vermeyi seven, adet edinen: "açıg todurgan/taturgan (aslı todgurgan)"; "aş taturgan” (Kaşgarlı

Türk Beslenme ve Mutfak Kültürünün Tarihsel Gelişimi ve Temel Belirleyicileri için bkz. Dinç, 2021: s.291-294.

Türk ailesinin tarih içerisindeki sosyokültürel değişimi ve tekâmülü için bkz. Gökalp, 1992: s.1080-1099; Gökalp, 1982: s.238-240.

$4 \quad$ Kadının kültürümüzdeki yeri için bkz. Nirun, 1994: s.315-326.

Adres $\mid$ Address

RumeliDE Dil ve Edebiyat Araştırmaları Dergisi $\quad$ RumeliDE Journal of Language and Literature Studies Osmanağa Mahallesi, Mürver Çiçeği Sokak, No:14/8 Osmanağa Mahallesi, Mürver Çiçeği Sokak, No:14/8

Kadıköy - İSTANBUL / TÜRKIYE 34714 Kadıköy - ISTANBUL / TURKEY 34714 e-posta: editor@rumelide.com

e-mail: editor@rumelide.com

tel: +90 505 7958124, +90 216773 o 616 phone: +90 505 7958124, +90 2167730616 
Mahmud, 2015: s.225) erler parmakla gösterilerek övülürken; yemek vermekten çekinen, misafirden kaçan ve onları kaçıranlar ise "konıknı kaçurgan"; "kişike kıçurgan" (Kaşgarlı Mahmud, 2015: s.226) tipler yerilir. Konu ile ilgili: tünet-; konukla-; konuklaş-; konuklug(k) ew; aşat- (Kaşgarlı Mahmud, 2015: s.330, 485, 308, 221, 102) kelimeleri de yer alır.

Çin ve Fransız mutfağı ile birlikte dünyada en önemli üç mutfaktan birisi olan Türk mutfağı (Duvarcı, 2002: s.397; Kut, 2002: s.368; Dinç, 2021: s.312) Türkün konukseverliği ile anlam kazanır. Farklı yüzyıllarda ve başka coğrafyalarda Türklerle çeşitli sebeplerle münasebette bulunmuş yabancı seyyah, yazar, şair ve düşünürler de eserlerinde Türkün bu erdeminden bahsederler: Du Loir, J. Pardoe, Voltaire, Demetrius Georgiades, L. de Contenson, Th. Thornton, Lamartine (Tezcan, 1974: s.31-33); İbn Battuta (Eröz, 1998: s.33-34).

Türklerde misafirlerin ağırlanması, ağırlanacağı -eğer yatıya kalacaklarsa dinlenecekleri- mekânın vasıfları, onlara ayrılan, onlara özel sunulan yiyecek ve içecekler, hane halkının hâl ve hareketleri, samimiyeti, içtenliği, güler yüzü, misafir ile vedalaşırken verilecek armağanlar gibi çokça olgu ve eylemi içerisinde barındıran bir süreçtir. Böylelikle Türklerde yemek, yalnızca fiziksel bir eylem olmaktan çıkar, yemek ve etrafında oluşan ritüeller ile misafirlerin karşılanmasından uğurlanmasına dek yaşananlar, veren ve yiyen arasında bir hukuk tesis eder.

Bu ilişkiyi gösterir bir deyim olan “tuz-ekmek hakkı” Elçin’e göre, dostluk, vefa, arkadaşlık, sadâkat, insanlık, samimiyet, merdlik ve dürüstlük... gibi türlü kavramları içine alan zengin bir klişedir. Hatta bu deyim Türkler arasında bir yemin ve nâmus sözü hükmünde ve değerindedir (1997: s.457,464). Törensel anlamı olan toplu yemeklerde de misafirlere ikram edilen, yiyeceklerden tutun ikram şekline kadar simgesel bir süreç işler (Beşirli, 2011a: s.111).

Dîvânu Lugâti't-Türk'e göre ise aş; insan vücudunda doyum sağlamanın yanında veren kişinin ününün insanlar arasında yayılmasına, fakirliğin önlenmesine, dertlerin giderilmesine, ahiret saadetine vesiledir. Öğütlerde ve ölen kişinin ardından terennüm edilen ağıtlarda aşın konu edilmesi açları doyurmanın Tanrı Teala tarafından önemsendiğini gösterir. Zira yakılan ağıtlar ölen kişi için bir nevi Yaradan'a yakarıştır, kalanların ise buna şahitliğidir.

"Körklüg tonug özünke

Tatlıg aşıg adınka

Tutgll konuk agırlıg

Yadsun çawın bodunka”5 (Kaşgarlı Mahmud, 2015: s.21).

"Kelse kalı yarlıg bolup yunçı̆̆ üme

Keldür anuk bolmış aşıg tutma uma”6 (Kaşgarlı Mahmud, 2015: s.44).

"Erdi aşın taturgan

Yawlak yagıg kaçurgan

Ugrak süsin kaytargan

$5 \quad$ Güzel elbiseyi kendin giy; lezzetli yemeği başkasına yedir, misafiri ağırla; böylece bunlar ününü insanlar arasında yaysın (Kaşgarlı Mahmud, 2015: s.21).

Sana hali perişan ve kederli bir misafir gelirse ona hazır yemekleri çıkar, yardımında gecikme (Kaşgarlı Mahmud, 2015: s.44).

Adres
RumeliDE Dil ve Edebiyat Arașttrmaları Dergisi Osmanağa Mahallesi, Mürver Çiçeği Sokak, No:14/8 Kadıköy - ÍSTANBUL / TÜRKIYE 34714 e-posta: editor@rumelide.com tel: +90 $5057958124,+902167730616$
Address

RumeliDE Journal of Language and Literature Studies

Osmanağa Mahallesi, Mürver Çiçeği Sokak, No:14/8

Kadıköy - ISTANBUL / TURKEY 34714

e-mail: editor@rumelide.com,

phone: +90 505 7958124, +90 2167730616 
Bastı ölüm axtaru”7 (Kaşgarlı Mahmud, 2015: s.225).

"Erdi aşın taturgan

Yawlak yagig katargan

Boynin tutup kadırgan

Bastı ölüm agtaru”8 (Kaşgarlı Mahmud, 2015: s.253).

“Turgan ulug ışlaka

Tirgi urup aşlaka

Tumlug kadır kışlaka

Kodtı ergi umduru”9 (Kaşgarlı Mahmud, 2015: s.248).

Kaşgarlı'da, değişen zamana bu güzel haslet direnemez ve misafirperver insanların yerini evine konuk gelecek diye içine korku düşenler alır.

"Bardı eren konuk körüp kutka sakar

Kaldı yawuz oyuk körüp ewni yıkar”1o (Kaşgarlı Mahmud, 2015: s.40).

"Bardı eren konuk bulup kutka sakar

Kaldı alıg oyuk körüp ewni yıkar”11 (Kaşgarlı Mahmud, 2015: s.165).

“Ötrük utun ogrılayu yüzke bakar

Elgin tüşüp birmiş aşı̆̆ başra kakar”12 (Kaşgarlı Mahmud, 2015: s.50).

Kaşgarlı gördüklerinden yola çlkarak bu neticeye varmış olsa da kendi kültür köklerini muhafaza eden Türk ailesinde; konukseverlik eski stereotiplerde olduğu gibi günümüz Türk toplumunda da hiç değişmeden devam etmiş bir meziyettir. Türk denilince: "Buyrun oturalım!" sözünün akla gelmesi, eskiden camilerde dahi misafirhanenin olması, "Konuk kısmeti ile gelir. Konuk on kısmetle gelir; birini yer dokuzunu bırakır" inancı. Bu inancın: "Her geleni Hızır bil.” fikri ile güçlendirilmesi Türkün misafirperverliğini gösterir (Tezcan, 1974: s.219-222).

Haneye gelenlerin memnun edilememesi ev sahibi için bir utançtır. Lâkin burada toplumun kınamasından ziyade inanç esaslı bir bakış açısı mevcuttur. Çünkü eve gelen, esasen Allah'ın ev sahibine kutlu bir armağanıdır. Misafirin duası makbul iken iyi ağırlanmayan misafir ise ev sahibine bedduadır:

“Kolsa kalı ugrapan birgil takı azukluk

O, misafirlere yemek yediren, düşmanlarını kovan, sarsılmazlığı ile Uğrak askerlerini püskürten idi. Tâ ölüm onu yıkıncaya kadar (Kaşgarlı Mahmud, 2015: s.225).

Adam yemek tattıran idi. Düşman sürüsünü geri püskürten idi. Boyunlarını buran idi. Ölüm onu yere serinceye kadar (Kaşgarlı Mahmud, 2015: s.253).

$\mathrm{O}$, her zaman büyük işlerin altından kalkardı. Kışın dondurucu günlerinde doyuran ve devamlı sofra seren idi. İnsanları terk etti ve onları hayır ve cömertliğine hasret bıraktı (Kaşgarlı Mahmud, 2015: s.248).

1o Bir misafir bulunca onu devlet ve uğur sayanlar gitti; çölde bir işaret taşı veya korkuluk görünce, kendilerine misafir inmesin diye korkularından çadırlarını yıkanlar kaldı” (Kaşgarlı Mahmud, 2015: s.40).

${ }_{11}$ Misafiri uğur sayanlar gitti. Bir hayal gördükleri zaman, o gelmesin diye çadırlarını yıkanlar kaldı (Kaşgarlı Mahmud, 2015: s.165).

Bugün sadece hilekâr ve adi adamlar kaldı. Konuğunun yüzüne hırsızmış gibi bakar. Yedirdiğini başına kakarak yolcu konuğunu minnet altında bırakır (Kaşgarlı Mahmud, 2015: s.50).

Adres $\mid$ Address 
Kargış kllur ümeler yunçıg körüp konukluk"13 (Kaşgarlı Mahmud, 2015: s.123).

Misafir gelmeyen kara evlere Dedem Korkut da kargış söyler:

"Konugı gelmeyen kara ivler yıkılsa yı" (Ergin, 2014: s.74).

Dîvânu Lugâti't-Türk başta olmak üzere yerli yabancı eserlerden hareketle verilen örneklerden Türkün misafirinden sevgisini, konuğundan hürmetini eksik etmediği anlaşlır. Tezcan Türkün bu karakterini, eski stereotiplerde olduğu gibi, konuk ağırlamak başlı başına bir değerdir (200oc: s.230-234), bu değer modern kent yaşamında özellikle "kabul günleri" vasıtasıyla ocak sahibi kadın ile canlı bir biçimde yaşatılmaktadır (200ob: s.201-209) tezi ile geçmişten günümüze taşır.

Konukseverliğin doğal bir sonucu olan misafire ikram etme düşüncesi Türkün muhayyilesinde asırlarca yaşamış, bu fikir Türk deyimlerinden atasözlerine, halk hikâyelerinden destanlarına kadar bütün türlerde kendisine yaşama imkânı bulmuşstur. Hatta Türklerde yemek yeme ve mutfak kültürü ile ilgili olarak bilgiler ihtiva eden, bir bakıma vesika niteliği gösteren (Kaya, 2007: s.7-8), Halk edebiyatının önemli mahsullerinden âşık destanları içerisinde hususi olarak işlenen "yemek destanları" mevcuttur. Bu mahsuller, kültürümüzde milli yemeklerimiz hakkında bilgi verme, yemek çeşitlerinin adlarını yaşatma, Türk sözcük hazinesine ve ad verme hususunda Halk Bilimine katkıda bulunma (Kaya, 2007: s.7-8) gibi önemli fonksiyonlara sahiptir.

\section{Sofra açma ve toplumsal cinsiyet}

Tüketen ilkel insandan, üreten topluma geçiş insanlık için önemli bir adımdır. Akın'a göre, bu evrimleşme sürecinde erkek av peşinde iken kadın çocukları yetiştirir, ev ekonomisini düzenler ve belki de modern toplumun temelini atacak eylemi başlatır; yani tarımı keşfeder (1991:111). Bu eylemi ile medeniyetin önemli bir merhalesine, salt tüketici toplumu üretici konuma getirerek adını yazdıran kadın, tarım ürünlerinden elde edilen mahsulleri işleyerek de sofranın kurulmasını sağlar. Standage kadının tarımı başlatmasındaki ilk merhaleyi besinin tarihteki ilk dönüştürücü rolü (2016: s.11) olarak tanımlar ve besinin uygarlıkların temelini oluşturmada kendisini gösterdiğini (2016: s.11) ifade eder. Kadın böylesine önemli bu rolü üstlenmesine rağmen Türk tefekküründe yemeği veren, sofrayı açan ekseriyetle erkektir.

Oğuz Ata'dan başlayan orun ve ülüş (İnan, 1998: s.241-254) geleneği, Türkün asırlar süren medeniyet telakkisi; sofra ${ }^{14}$ (kendürük ${ }^{15}$ ) sermenin/yaymanın, sofra adabının, sofra düzeninin de sistematik bir hal almasını sağlar. Aşın taksimi ve oturma düzeninin kültürel izleri günümüzde de görülür. Yemeğinaşın kutu, konukların ululuğu; Türk milletinin varolduğu ilk zamanlardan itibaren zihinlerde kendisini korur ve İslâmiyet’in misafirin bereket getireceği inancı ile birleşerek güç kazanır. Söz konusu kutu ocağa getirecek yani sofrayı kuracak kişi ise tabiatıyla misafirini ağırlamayı bilen, eşinin yüzünü ak edecek kadındır.

Kadınların tasnifinin ev hayatına göre yapıldı̆̆ı (Kaplan, 2006: s.49) Dede Korkut’ta toplumun istediği ve zihninde yer eden bu kutlu kadının profili asırlar öncesinden çizilir. O, konukları ağırlamasını bildiği için Ehli Beyt soyundan diyerek övülür, "evin dayağı” biçiminde vasıflandırılır: "Ozan ivün

Ĕger bir misafir senden yiyecek isterse ve onu için sana gelirse ona ver; çünkü ağırlama kötü ise misafir ev sahibine lanet eder (Kaşgarlı Mahmud, 2015: s.123).

"Sofra" aslında sefere çıkan için yapılan yemeğin adıdır; fakat sonradan üzerine yemek koyduğumuz nesnenin adı olur (Kaşgarlı Mahmud, 2015: s.160).

Dede Korkut Oğuzlarında üzerinde yemek yenilen bir çeşit yaygı (Gökyay, 2007: s.1145)

Adres Address

RumeliDE Dil ve Edebiyat Araştrmalarn Dergisi $\quad$ RumeliDE Journal of Language and Literature Studies Osmanağa Mahallesi, Mürver Çiçeği Sokak, No:14/8 Osmanağa Mahallesi, Mürver Çiçeği Sokak, No:14/8

Kadıköy - İSTANBUL / TÜRKIYE 34714 Kadıköy - ISTANBUL / TURKEY 34714 e-posta: editor@rumelide.com

e-mail: editor@rumelide.com

tel: +90 $5057958124,+90216773$ o 616 phone: +90 505 7958124, +90 216773 o 616 
tayağı oldur ki yazıdan yabandan ive bir konuk gelse, er adam ivde olmasa, ol anı yidürür içürür ağırlar azizler gönderür. Ol Ayişe Fatıma soyıdur. Anun bebeklerü yetsün. Ocağuna bunçllayın avrat gelsün" (Ergin, 2014: s.76) Olumsuz üç kadın tipi ise "solduran sop, tolduran top, niçe söylerisen bayağı" hususiyle ev işlerini aksatmaları, gelen misafirleri iyi ağırlamamaları ile eleştirilir (Ergin, 2014: s.7677).

Kadın, kızını misafirin kutuna inanan Türkün töresine uygun yetiştirmekle de görevlidir. Bu sebepten anaya benzeyen soylu kıza "anaç", babasına çekmiş oğlana da "ataç" derler (Güler, 1998: s.56); çünkü kız meziyetlerini annesinden, oğul ise babasından alır: "Kız anadan görmeyinçe ögüt almaz, oğul atadan görmeyince sufra çekmez" (Ergin, 2014: s.74).

Kadın, ocağın tütmesine vesile olsa da kız çocuk, erkek çocuktan genellikle arka plânda veya farklı bir konumdadır: "Oğlı olanı ağ otağa kızı olanı kızıl otağa kondurun" (Ergin, 2014: s.78). Radloff un Kazak Türkleri arasında kaydettiği, düğünlerde geline kırmızı giydirilmesi, kırmızı başlık takılması, kızın kızıl otağa oturtulmasının bir yansıması olabilir (1956: s.486). Çünkü kız çocuk, el gelini addedilir. Radloff'un gözlemlerine göre, yabancı bir diyarda evin hâkimi olmak kızın takdiridir (1956: s.490). Üstelik Türkün bilincinde kız yenilgiyi, olumsuz sonucu nitelendirirken tam tersi anlamda ise muzafferiyeti, olumlu neticeleri erkek karşılar. Kam Püre Oğlu Bamsı Beyrek Boyunda, Delü Karçar ile mücadeleden gelen Dede Korkut'a, Pay Püre neticeyi kız-erkek ayrımını gösterir bir yaklaşımla sorar: "Dede oğlan mısın kız mısın?" Dede Korkut ise muştuyu verir: "Dede oğlanam didi” (Ergin, 2014: s.127). Günümüzde doğan çocuk erkekse, evde büyük bir sevinç hüküm sürer, halbuki kız olduğu zaman kayıtsızlıkla karşlanır (Radloff, 1956: s.485); hatta oğlan çocuk tek ise bazan kız kardeşinden ve hattâ anasindan yüksek tutulur (Radloff, 1956: s.485).

Kadının erkeğe benzedikçe statü kazandığı, fiziksel anlamda yaratılışı gereği davrandığı zaman toplumsal yapının betimlemesi içerisinde kendine yer bulamadığı, kadınsı vasıflarını terk edip erkeğe benzedikçe, erkek hasletleri kazandıkça statü kazandığı (Uygur, 2013: s.402) fikri Orta Asya'da uçsuz bucaksız bozkırlarda yaşayan Oğuz'un hem geçim kaynakları hayvancılık hem de içeri ve dışarıdaki düşmanların varlığı; yani siyasi, sosyal ve ekonomik yaşam şartları gereği güce ihtiyaç duyması ile açıklanabilir. Lakin Türk Destanlarında kahramanı kadın olan anlatılarda fiziki ve fikri manada erkeklerden aşağı kalmayan kadın kahramanın kendisinden daha zayıf bir karakter gösteren abisinin atının önüne geçecek olan atını durdurması (Aktaş, 2011: s.58-96,106-108), günümüz Altay Türkleri içerisinde yeni doğan çocuğun cinsiyetinin gerekli mi -erkek-, gereksiz mi -kız- biçiminde öğrenilmeye çalışılması ve cinsiyete göre toy yapılması (Dilek, s.1996: 51,52), Anadoluda hala varlığını koruyan geçiş dönemi ritüellerinde erkeğe ait törenlerin daha güçlü ve şaşaalı yapılması, kızın töreninin ya hiç olmaması veya sönük geçmesi, hatta kız tarafının bu törenleri sahiplenmeyip az iştirak göstermesi, düğünü erkek tarafı kurar fikri, miras mevzu bahis olunca yine kız çocuğa ya pay verilmemesi ya da "gönül görme-gönül alma" adı altında küçük hediyelerle kızın vazgeçirilmesi, ne Oğuz Boylarında ne de günümüz modern Türk toplumunda sadece güce olan ihtiyaç ile açıklanabilir.

Kurban edilen hayvanların dahi makbul olanının dişi değil erkek olması toplumsal cinsiyet bağlamında manidardır. Ergin'in geniş katılımlı Oğuz toylarında hayvanların erkek olanları, aygır-buğra-koç, tercih edilir ve bu uğurda kurban edilir (2014: s.73-251) tespiti ekonomik, dini ve kültürel alt yapıya sahiptir. Dişi hayvanın kurban edilmesi, türün çoğalmasına engel olması ve aynı hayvandan elde edilen diğer ürünlerin süt, yoğurt, ayran, ağız, peynir, tereyă̆ı vs. azalması ekonomik; koçun güç, prestij ve kesen/kestiren kişinin statüsünü göstermesi bakımından koyuna nazaran daha belirleyici olması sosyokültürel; Hz. İsmail (as)'in yerine kurban edilmesi için Hz. İbrahim (as)'e cennetten

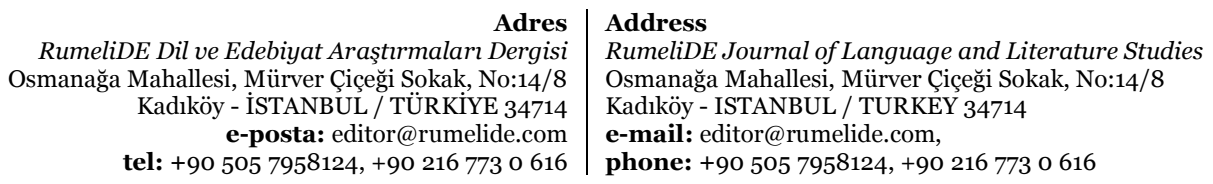


gönderildiğine inanılan, Hz. Peygamber (sav)'in pratiklerinde -hadis-i şerif- görülen hayvanın cinsinin yine erkek -koç- olması bu fikrin dinî yönünü göstermektedir.

İslâmi devirde ibadet gibi bir mâna ve fonksiyona (Kaplan, 1979: s.36) sahip geniş sofraların, günümüzde devam eden ve Dede Korkut'ta örneğini gördüğümüz, ebeveynlerin çocuk sahibi olabilmek için açların doyurulması gibi özel sebeplerden ötürü de serildiği görülür. Közleme, konuya hadis-i şerif ölçüsünde bakar; yemeğe bereket kazandırmak, birlik ve muhabbeti artırmak için Hz. Peygamber (sav)'in toplu halde yemek yemeyi tavsiye ettiğini (2012: s.228) kaydeder. Sosyo-ekonomik süreç göz önünde bulundurulduğunda ise yemeğin sosyal işlevinin temelinde paylaşılma özelliği olduğu (Abdurrezzak, 2014: s.13) görülür.

\section{Kutsuz aș}

Anadolu'ya tarih boyunca siyasî, sosyal, ekonomik ve dinî nedenlerden ötürü Türk göçleri olur, Türkler Anadolu'yu öz yurtları Orta Asya gibi vatan bilir ve yerleşirler. Asırlar süren göçlerle Oğuz Boyları bölgeye kendi görenek ve inançlarını taşırlar. Farklı zamanlarda vuku bulan siyasi, ekonomik, dini, sosyal sebepler neticesinde boylar bölgede yer değiştirir, Anadolu'da iç göçler yaşanır.

Horasan'dan Anadolu’ya gelip bugünkü İç Anadolu'ya yerleşen ve çeşitli sebeplerden güneye inmek zorunda kalan/bırakılan, seksen bin haneden müteşekkil Barak Türkmenleri, Batıda Amanoslar ve Amik Ovasından doğuda Fırat Nehri'ne; Güneyde Halep’ten kuzeyde Adıyaman sınırlarına kadar geniş bir bölgede meskundurlar. Tilbaşar Yaylası (Tilbaşar Mezeresi-Barak Ovası) olarak da bilinen yöre, Türkmenlerin iç göçlerle İç Anadolu'dan gelip yurt tuttukları yörelerden birisidir. Günümüze kadar Suriye sınırlarında, bilhassa Halep ve kuzeyinde, yerleşik Barak köyleri varlıklarını ve öz kültürlerini korumaktayken Suriye'de yaşanan iç savaş neticesinde Türkmenlerin bir kısmı Anadolu'ya geçip akrabalarının köy ve mahallelerine yerleşmiştir.

Bölgeye bahsedilen göç dalgası ile gelip iki kol halinde Halep ve Gaziantep’in Oğuzeli ilçesi sınırlarına yerleşen bir aile de Oğuz'un Bayat boyuna mensup Çarganlılar'dır. Çarganlı Ailesi önceleri, Tilbaşar'da meskûn mağaralarda farklı aileler ile birlikte yaşar. Yörede aileler arasında yaşanan sert münakaşalar başka aileden iki-üç kişinin ölmesi ile çatışmaya dönüşür. Husumetin büyümesini engellemek isteyen Çarganlılar göç ederler. Yaşanan hadiselerden sonra "Çarganlı" aileye ad olur: "çal-kan". İsim zamanla değişerek soyadı kanunu ile birlikte "Çalakan” biçiminde resmiyet kazanır. Farklı söyleyişlere sahip olsa da aile üyeleri kendilerinin "Çarganlı" olduklarını söylerler (KK5).

Bir nevi zorunlu göç eden Çarganlılar, Gaziantep’in Oğuzeli ilçesine bağlı Sevindi Köyü’ne yerleşip bir müddet burada yaşamlarını idame ettirirler. Ma'mo (Mehmed) Dede'nin zamanında, adı hâlâ Gebeköy olan köyü sahibi ağadan satın alır ve kendilerine Gebeköy’ü yurt tutarlar (KK5).

Köyün adı ise, çocuk sahibi olamamaktan muzdarip bir çiftin Çarganlılar'ın yeni yurdunda muratlarına ermesi ile konur. O zamanlarda, hayvanlarına otlak arayan konargöçer aileler (Yörük), mevsime göre üç-dört ay köy civarında konaklar. Konaklayan Yörük obalarından birinin şıhının (hoca/imam) eşi ise kısırdır, bu çift daha önce ne denerse denesin bir türlü evlat sahibi olamaz. Şıhın ihtiyar karısı, bu köye gelince yaşı geçkin olan kocasından hamile kalır. O günden sonra Yörükler birbirlerine yer yurt tarif ederken "şıhın eşinin gebe kaldığı yer" manasına "Gebeköy" derler, böylelikle zamanla köyün adı da oluşur (KK3, KK5). Civar köylerin adları da benzer biçimde ortaya çıkar: Dut ağacı olan köy: Dutluca;

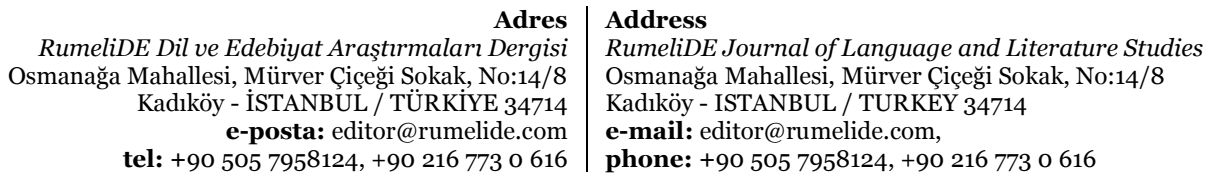


dere olan köy: Dereköy; muştu aldığımız yer: Sevindi Köyü; mahsulün toplandığı yer: Ambarcık; çift kuyulu yer: İkizkuyu gibi.

Misafirin baş tacı edilmesi gerektiği fikrine sahip Gebeköy özelinde oldu gibi Barak Ovası'nın her yerinde var olan "Evini sat, yüzünü ağart.” sözü, yöre Türkmenlerinin konukseverliğini gösterir. Gündelik yaşamlarında tüketemedikleri, yalnızca misafir ile birlikte ancak sofraya inen yiyeceklerin varlığı, başkasını kendi benliğine tercih düşüncesi ve konuklara verilen değere bakılacak olursa Türkün kadirşinaslığı ve yüce gönüllüğü akseder. Orta Asya'dan bu yana getirdiğimiz bu misafirperverlik Ersoy’a göre, günümüzde de devam etmekte, misafir ağırlanan sofralar ailenin sosyo-ekonomik şartlarına göre en mükemmel olacak şekilde düzenlenmektedir (2002: s.392).

Konuk ağırlama mevzu bahis olduğunda yani köyde rollerin taksimine gelince işlerin çoğunluğunu kadınların yaptığı görülür. Barak Ovası'na sirayet etmiş erkek egemenliğine dayalı bir cinsiyet ayrımı Gebeköy'de de vardır. Erkekler sadece tarla işleri ile -ekin, çift, gübre, yolma (mahsulün el ile toplanması)- kadınların da yardımı ile dönemsel olarak ilgilenirler, boş zamanlarını köy odasında geçirirler. Kadınlar ise yemek hazırlamaktan, çocukların bakımına, eğitimine hayli iş ile iştigal ettiklerinden boş vakte hayatlarında yer açamazlar. Onların sosyalleşmesi ve kültür aktarımı da imece usulü ile yaptıkları kış hazırlıkları ve sair hâne işleri ile olur.

Kadının toplumsal statüsünün ve değerinin İslâmiyet’ten sonra da küçük değişiklikler ile Türkler içerisinde aynı kaldığı fikrinde olan ve kadının ödevleri arasında güzelliği, namusunu muhafazayı ve hamaratlığı -ev işlerinde maharet- sayan Tezcan'a göre (1974: s.84-88), kışlık yiyeceklerin hazırlanması, kadınlar arasında yardımlaşma geleneğini doğurmuştur. Komşular birbirlerine yiyeceklerini hazırlarken yardım ederler. Erişte (ev makarnası) kesiminde, pekmez kaynatmada, salça yapımında, turşu kurmada, tarhana yapımında olduğu gibi bu gelenek, toplumsal dayanışmanın en güzel ifadesi olmuştur (1982: s.114). Benzer bir görüşü paylaşan Goode, yemek hazırlamanın diğer birçok karmaşık aşamaları da (kap-kacak, pişirme ve yapılanlar) sosyal ve kültürel mesajların aktarılmasını sağladığı; son olarak yemek yeme olayları, kendiliğinden sosyal roller ve ilişkilerle ilgili temel mesajların aktarımı için iletişimsel olay olabileceğini (2009: s.375) aktarır.

Gebeköy'de kadınların mahareti hususi günlerde yaptıkları çeşitli ve zahmetli yemeklerde görülür. Ramazan Bayramı'nda misafirlere yuvarlama ve kâhke (bir çeşit kışlık/kurut sert kurabiye); mevlitlerde ise şeker şerbeti ikram edilir. Dügünlerde yine yöresel bir lezzet olan şivediz (ana malzemesi sarımsak olan yoğurtlu bir çorba) hazırlanır. Özel günlerin en muteber yemeği ise pilav ile cıvıktır (doğrama, çeşitli mevsim sebzelerinden yapılan sulu yemek). Ölünün kırkında koyun kellesi (baş) bütün bir biçimde pişirilip pilav üstüne konarak gelenlere sunulur. Kırkıncı günde ayriyeten ölünün sevabına, komşulara, hane halkı sayısınca açma ekmek (sacda yapılan yufka) ve tahin helvası dağıtmak da önemli bir ritüeldir. Ölü aşında, kelle sayısının fazlalığı yani kesilen koyunun çok olması aşı veren kişinin güç, otorite ve misafirperverliğini göstermesi bakımından mühimdir. Ayrıca kelle, misafirlerden en itibarlı ve büyük olanının önüne konur (KK5, KK1, KK2).

Barak Ovası'nda olduğu gibi; yemek malzemeleri, bir etnik veya sınıfsal grubun sinırlarında olduğu gibi bir bireyin statüsünü işaret etmek için de kullanılabilir (Goode, 2009: s.375) görüşünü genelleyen Beşirli'ye göre, Türklerdeki toylar ve hükümdar yemekleri, ziyafeti düzenleyenin toplumsal statüsünü gösterir (2010: s.162), bununla beraber yiyecekler konuklara sosyal ve siyasal hiyerarşilerini ifade eden belirli sırayla ikram edilir (2011b: s.142).

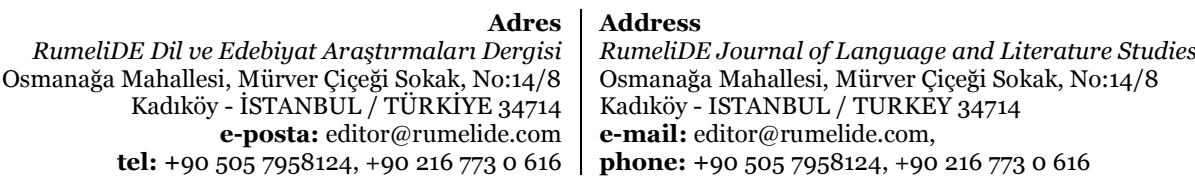


Yemeğin sadece bir eylem olmaktan çıkıp ayrı bir sosyolojiye haiz olduğu Barak Ovası'nda "kurut" önemli bir gıda saklama ve muhafaza yöntemidir. Bölgenin sert bozkır iklimi düşünüldüğünde kışa hazırlık tekniği daha iyi anlaşılacaktır. Hayvanların kışın veriminin düşmesi, tarımdan herhangi bir mahsul elde edilememesi, kış şartlarının ağır geçmesinden ötürü gelir getiren sair işlerin de aksaması, bölge insanının ilkbaharda başlayıp yaz mevsiminin sonuna kadar devam eden tarımsal üretimden elde edilen mahsulün bir kısmını bozulmadan kışa hazırlamaya itmiştir. Bölgede patlıcan, biber, haylan (su kabağı), acur (bir çeşit tüylü salatalık), bamya, domates, pirpirim (semiz otu), fasulye gibi yaz sebzeleri basit manada gerekiyorsa içleri de oyularak ipe dizilir, güneşe asılarak-güneşte bekletilerek kurutmalık yahut dolmalık yapılır ve kışın bu kurutlarla çeşitli yemekler hazırlanır.

Tilbaşar Yaylasının uzun kış gün ve gecelerinde tüketilen tatlı, atıştırmalık ve bazı kahvaltılıklar da benzer yöntemle elde edilir. Yazın bağ ve bahçelerden toplanan dut ve üzümler; pekmez, şıra ve kuru yapılarak korunur. Üzüm ve dut pekmezi ile yine yaz mahsulü cevizin ve yörenin önemli geçim kaynaklarından birisi Antep fistığının belirli yöntemlerle bir araya getirilmesi ile zortaha, dilme, kesme, bastık, muska, cevizli sucuk, kabak reçeli (pekmezden) gibi yöresel tatlılar yapılır. Bölgede incir de hem reçeli yapılan hem de kışın tüketilen önemli kurutlardandır.

Sofra geleneği zengin olan ve bazı yemeklerin insanların zihninde çeşitli örtük ya da açık çağrışımlar yaptığı bu yörede farklı bir inanış biçiminin ortaya çımasına neden olan tarhana, Tezcan'a göre, bozkır kültürünün yapısına uygun olmakla birlikte yazın hazırlanıp kışın tüketilen bir yiyecek türüdür. Türk mutfağında önemli bir yeri olan yoğurdun bozulmadan kışa saklanabilmesi için bulunmuş olan bir yöntemdir (2000a: s.124). Osmanlı döneminin de en favori yemekleri çorbalardır (Şavkay, 1992: s.812). Bu sebepten çorbalar, Türk mutfağında tüketilen gıdalar mevzu bahis olduğunda ekseriyetle ilk sırada zikredilir (Dinç, 2021: s.294-296).

Türkün en bilinen ve yaygın kurutlarından birisi olan tarhanadan Gebeköy'de tarhana çorbası, tarhana böreği, tarhana sıkmacı gibi çeşitli yemekler yapılır. Yalnız, bozkırın meşhur kurutmalığı tarhananın Çarganlılar'da dökülmesi, alınması ve yemeklerde kullanılması, uğursuzluk getireceğine inanıldığından yasaktır. Tarhananın adının zikredilmesi dahi hoş karşılanmaz. Bu inanç ailenin başına gelen türlü felaketlerden sonra şekillenmiş, tüm aile bireyleri hususen kadınlar buna kâni olmuşlardır (KK6, KK4).

Kutsuz saydıkları bu aş yüzünden başlarına türlü musibetler gelen Çarganlılar'ın tarhana döktükleri bir günde Ma'mo'nun amcasının oğlu vefat eder. Başka bir gün ailenin evine Medine Gari'nin (kadın) Ma'mo'nun eşi- erkek kardeşinin oğlu Antep’ten ziyarete gelir. Gelinleri köye gelmişken kurutmalık diye tarhana yapıp evine götürmek ister. Medine Gari misafirin isteğini geri çeviremez. Çünkü inançlarına göre misafir kutu ile birlikte gelir. Gelinleri geceden evlerinde kalır. Medine Gari’yi bir düşünce, kaygı alır; öyle ki sabahı zor eder. Nihayetinde sabah olur. Gün doğmadan havuşta (eski kerpiç evlerde üstü açı avlu) tarhana hazırlıkları başlar. Ocak kemre (tezek) ile yakılır. Kazana kaynaması için su konur. Medine Gari kaynayan suya dövmeyi (yarma, aşurelik buğday) koyarken; gösterişli, iri koçlarını kastederek: "Allah’ım canımızdan alma en tavlı (gösterişli, iri) malımızı al!" der. Daha dövme kaynarken eşeğin sırtında kanlar içinde tavlı koç ile köyün çobanı çıkagelir. Meğer koç yabanda fenalaşır, koçun kötüleştiğini gören çoban da hayvanı keser. Medine Gari olaydan sonra tarhana kelimesinin zikrine dahi mâni olur. Ailenin tarhana aşına karşı olan inancı daha da pekişir $\left(\mathrm{KK}_{5}\right)$.

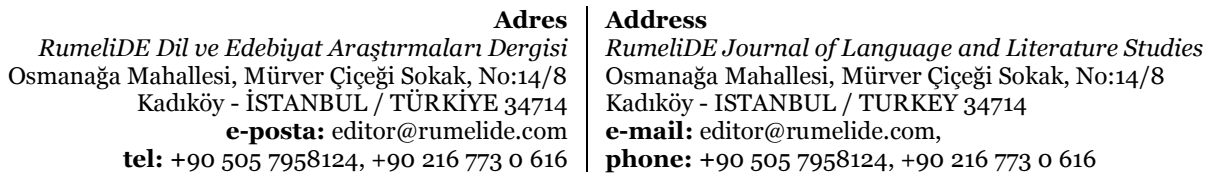


Günümüzde de Çarganlılar'da tarhana pişirmek yasaktır. Tarhana dökmeye başlarına bir felaket gelir düşüncesiyle cesaret edemezler. Tarhana yapacak kişi olası felaketlerin vebalinden ve cezasının kendisine kesilmesinden korkar, çekinir. Aşın şakasının dahi yapılması hoş karşılanmaz (KK6, KK1).

Gelin olup evden ayrılan kızlar eğer aile içi evlilik yapmışlarsa ritüeli devam ettirirken, başka bir aile ile hayatını birleştiren kızlar kutsuzluğun bozulduğuna inandıklarından tarhana döker ve pişirirler. Tersi bir durumda yani; aşın kutsuzluğuna inanan aileden, Çarganlılar, birisi ile hayatını birleştiren kız tarhanayı uğursuz sayar, tarhana dökmez; yalnız satın alır veya hediyeleri, ikramları aş yapar (KK5, KK6; KK4).

Erkek otoritesine dayalı bu ve benzer aile yapılarında kız çocuklar hem yetiştikleri hem de gelin gidecekleri ailede erkeğin otoritesine tabi olur, ataerkil yapıyı sorgulamaksızın uyum sağlamak üzere yetiştirilirler (Tolan, 1991: s.209). Gebeköy ve aşın kutu özelinde ataerkil aile yapısında, ocak ve ocă̆ın sürerliği, sönmesi erkeğe aittir. Kocasının ocağına giren ve ona tabi olan kadın yalnızca ocak değiştirmekle kalmaz, kocasının ocağının inancını da şartsız kabul edip paylaşır.

\section{Sonuç}

İlkel avcı toplayıcılıktan modern çağlarda üretici konuma geçen bireyden, klan ailesinden çağdaş çekirdek aileye evrilmiş en küçük topluluğa, kabile yaşantısından küresel topluma geçiş yapan insana değin insanoğlu yaşantısının sürerliğini sosyal bir varlık olmasına borçludur. Sosyal olmak, diğer insanlarla münasebette bulunmak bir zorunluluk ve ihtiyaçtır. Bu zorunluluk onun toplumsallaşmasını sağlar ve yapılacak işlerde görev dağılımını gerekli kılar. Vazifeler taksim edilirken ise temelde iki cinsiyet farklı rollere büründürülür.

Toprağı işleyerek anaerkil dönemi sonlandırıp ataerkil aile yapısını kuran, insanlığı ileri medeniyetlere doğru çă̆ atlatan kadının görevleri hangi aile tipi-oluşumu söz konusu olursa olsun toplumun cinsiyetlere yüklediği roller esasında niceliksel olarak fazla, nitelik açıdan daha çeşitlidir.

Kadın egemen, erkek egemen ve modern zamanların eşitlikçi ailesinde kadın sorumluluklarını bihakkın yerine getirirken, salt ev işlerinde hamaratlık, kadınlık vazifeleri değil; onun kültürel birikimi aktarım eylemi de çocukların eğitiminden sorumlu olması da hemen hiçbir değişikliğe uğramaz. Hatta iş hayatına atılması, çalışan kadın kavramı, "müşterek hayatı" bilhassa mutfağa/ocağa çoğunlukla taşıyamaz.

Ocak, kendisine özel bir yaşam alanı ve zamanı yaratamayan Türkmen kadınının hemcinsleri ile sıkıntılarını paylaştığı, dertlerini bölüştüğü, sevinçlerini çoğalttığı, haber alıp verdiği özel bir mekândır. Geleneğin önemli temsilcisi kadın, aynı zamanda birikimlerini de bu ocakta aktarma firsatı bulur. Böylelikle gelenek ve göreneğin sürdürülebilirliği ve ortaya çıkacak yeni inanmaların inşası da söz konusu eylemi ile baskın bir karakter sergileyen kadın ile olur. Halk inanmaları bazen bir kuşak sonrasında oluşurken bazen de kimi ananelerin varyantlaşması dahi yüzyıllar sürebilmektedir.

Barak Ovası'nda otorite, ocak sahibi erkek olsa da ocağın kutu, bereketi kadın iledir. Barak mutfağının ünü ise yalnızca ocağındaki yemek çeşitliliği ve lezzetinden değil; Türk ocağının "Misafir on rızık getirir, birisini yer, dokuzunu ev sahibine bırakıp gider” inanması ile çevrelenmesindendir.

Ocağın ateşini harlayan Çarganlı kadınının tarhana aşının kutsuzluğuna inancı ve kutlu günlerde yaptığı hususi yemeklerde olduğu gibi bağlamı ile konuklara türlü mesajlar veren aş ve etrafında

\begin{tabular}{|c|c|}
\hline Adres & ddd \\
\hline $\operatorname{arl} \mathrm{De}$ & DE Jou \\
\hline Mahallesi, & Osmanağa Mahallesi, Mürver Çiçeği Sokak, No:14/8 \\
\hline Kadıköy - & Kadıköy - ISTANBUL / TURKEY 34714 \\
\hline $\begin{array}{r}\text { e-posta: editor@rumelide.com } \\
\text { tel: }+905057958124,+902167730616\end{array}$ & $\begin{array}{l}\text { e-mail: editor@rumelide.com, } \\
\text { phone: +90 505 7958124, +90 } 216773 \text { o } 616\end{array}$ \\
\hline
\end{tabular}


oluşan halk inanmaları Türkün kimliğiyle hüküm sürdüğü coğrafyalarda araştırmacılarca incelenmeyi beklemektedir.

\section{Kaynakça}

Abdurrezzak, A. O. (2014). İşlevsel Teori Bağlamında Yemek Kültürünün İletişimsel Yönü. Turkish Studies, 9(11), 1-16.

Akın, E. (1991). Ananın Aile İçindeki Rolü. Türk Aile Ansiklopedisi I. Ankara: T.C. Başbakanlık Aile Araştırma Kurumu, 110-113.

Aktaş, E. (2011). Hakas Destanları III. Ankara: Türk Dil Kurumu.

Beşirli, H. (2010). Yemek, Kültür ve Kimlik. Milli Folklor, (87), 159-169.

Beşirli, H. (2011a). Dede Korkut Hikâyelerinde İktidar Göstergesi Olarak Yemek Sembolizmi. Yeşil, Y. (Editör). Dede Korkut ve Geçmişten Geleceğe Türk Destanları Uluslararası Sempozyumu. Ankara: TÜRKSOY, 103-113.

Beşirli, H. (2011b). Türk Kültüründe Güç, İktidar, İtaat ve Sadakatin Yemek Sembolizmi Esasında Değerlendirilmesi. Türk Kültürü ve Hacı Bektaşı Veli Araştırma Dergisi, (58), 139-152.

Dinç, M. (2021). Halk Bilgisinin Beslenme ve Mutfak Kültürüne Dönük Temsilleri. Aça, M. (Ed). Halk Bilimi El Kitabr. Ankara: Nobel Akademik, 287-314.

Dilek, İ. (1996). Altay Türklerinde Çocuğun Doğması ve Doğum Günü Kutlamalarına Dair Bazı İnanışlar. Bilig, (1), 51-55.

Duvarcı, A. (2002). Türklerde Yiyecek İçecek Kültürü. Güzel, C., Çiçek, K., Koca, S. (Ed). Türkler 4. Ankara: Yeni Türkiye Yayınları, 397-408.

Elçin, Ş. (1997). Halk Edebiyatı Araştırmaları II. Ankara: Akçağ.

Ergin, M. (2014). Dede Korkut Kitabı-1. Ankara: Türk Dil Kurumu.

Eröz, M. (1998). Türk Ailesi. Eröz, M., Güler, A. (Ed). Türk Ailesi. Ankara: Atatürk Kültür Merkezi Başkanlığ 1 1-20.

Ersoy, Y. (2002). Türk Mutfak Kültürü. Güzel, C., Çiçek, K., Koca, S. (Ed). Türkler 4. Ankara: Yeni Türkiye, 382-396.

Goode, J. (2009). Yemek (çev. Fatih MORMENEKŞE). Oğuz, Ö.; Gürçayır, S.; Çalış, S. (Yay. Hazırlayanlar). Halkbilimde Kuramlar ve Yaklaşımlar 3. Ankara: Geleneksel, 375-381.

Gökalp, Z. (1982). Türk Ailesinin Tekâmülü. Çay, M. A. (Haz). Makaleler VII. Ankara: Kültür Bakanllğ̆l, 238-240.

Gökalp, Z. (1992). Aile Ahlâkı. Sosyo-Kültürel Değișme Sürecinde Türk Ailesi III. Ankara: T.C. Başbakanlık Aile Araştırma Kurumu, 1080-1099.

Gökyay, O. Ș. (2007). Dedem Korkudun Kitabı. İstanbul: Kabalcı.

Güler, A. (1998). Türklerde Aile ve Unsurları. Eröz, M.; Güler, A. (Ed). Türk Ailesi. Ankara: Atatürk Kültür Merkezi Başkanlı̆̆ı, 44-66.

Güler, S. (2007). Türk Mutfağının Değișim Nedenleri Üzerine Genel Bir Değerlendirme. I. Ulusal Gastronomi Sempozyumu ve Sanatsal Etkinlikler. Antalya, 18-28.

İnan, A. (1998). Makaleler ve İncelemeler I. Ankara: Türk Tarihi Kurumu.

Kaplan, M. (1979). Ŏ̆uz Kağan Destanı. İstanbul: Dergâh.

Kaplan, M. (2006). Türk Edebiyatı Üzerinde Araştırmalar I. İstanbul: Dergâh.

Kaya, D. (2007). Halk Edebiyatında Yemek Destanları. Motif, (48), 4-11.

Kaşgarlı Mahmud. (2015). Dîvânu Lugâti’t-Türk Giriş-Metin-Çeviri-Notlar-Dizin. Ercilasun, A.B.; Akkoyunlu, Z. (Haz.). Ankara: Türk Dil Kurumu.

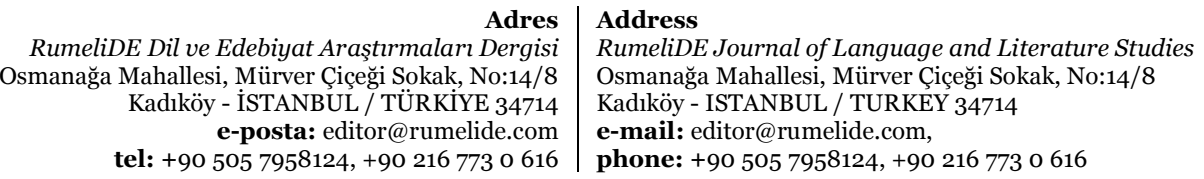


Közleme, O. (2012). İslam Mutfak Kültürü. Toplum Bilimleri Dergisi, 6(11), 219-229.

Közleme, O. (2013). Türk Mutfak Kültüründe Siyasi, Sosyal ve Dini Sembolizm. Toplum Bilimleri Dergisi, 7(14), 387-395.

Kurt, İ. (1992). Atasözlerinde Aile. Sosyo-Kültürel Değişme Sürecinde Türk Ailesi II. Ankara: T.C. Başbakanlık Aile Araştırma Kurumu, 625-649.

Kut, G. (2002). Türklerde Yemek Kültürü. Güzel, C., Çiçek, K., Koca, S. (Ed). Türkler 4. Ankara: Yeni Türkiye, 368-381.

Nirun, N. (1994). Sistematik Sosyoloji Yönünden Aile ve Kültür. Ankara: Atatürk Kültür Merkezi.

Öğüt Eker, G. (2018). Farkl Görme Biçimiyle Modern Dünya Ritüeli Olarak Yemek Kültürü: Sinanma/Erginlenme ve İntikam Alma Gizli İşlevleri. Milli Folklor, 30(120), 170-183.

Özdemir, H. (1991). Misafir ve Misafirperverlik. Türk Aile Ansiklopedisi II. Ankara: T.C. Başbakanlık Aile Araştırma Kurumu, 740-748.

Radloff, W. (1956). Sibirya'dan I. Temir, A. (Çev). İstanbul: Maarif Basımevi.

Standage, T. (2016). İnsanlığın Yeme Tarihi. Çakır, G. (Çev). İstanbul: Mayakitap.

Şavkay, T. (1992). Medeniyet ve Coğrafya Değişmeleri Çerçevesinde Türk Mutfağı. Sosyo-Kültürel Değişme Sürecinde Türk Ailesi II. Ankara: T.C. Başbakanlık Aile Araştırma Kurumu Yayınları, 805-816.

Tezcan, M. (1974). Türklerle İlgili Stereotipler (Kalpp Yargllar) ve Türk Değerleri Üzerine Bir Deneme. Ankara: Ankara Üniversitesi Ĕgitim Fakültesi.

Tezcan, M. (1982). Türklerde Yemek Yeme Alışkanlıkları ve Buna İlişkin Davranış Kalıpları. Türk Mutfă̆ı Sempozyumu Bildirileri. Ankara: Kültür ve Turizm Bakanlığı Milli Folklor Araştırma Dairesi, 113-121.

Tezcan, M. (2000a). Türk Yemek Antropolojisi Yazıları. Ankara: T.C. Kültür Bakanlığı.

Tezcan, M. (200ob). Türk Ailesi Antropolojisi. Ankara: İmge Kitabevi.

Tezcan, M. (2000c). Türk Kişiliği ve Kültür-Kişilik İlişkileri. Ankara: T.C. Kültür Bakanlığı.

Tolan, B. (1991). Aile, Cinsiyet ve Cinsel Roller. Türk Aile Ansiklopedisi I. Ankara: T.C. Başbakanlık Aile Araştırma Kurumu, 208-214.

Uygur, K. (2013). Dede Korkut Hikâyelerinde Kadın Statüsü. I. Uluslararası Türk Dili ve Edebiyatı Kongresi. Saraybosna: International Burch University, 385-403.

\section{Kaynak kişiler}

KK1: Esra ŞAHAN, 23 yaşında, üniversite mezunu, bekâr, öğretmen. (mülakat tarihi: 01.10.2020)

KK2: Fatma SARIGÜL, 55 yaşında, okur-yazar, bekâr, ev hanımı. (mülakat tarihi: 04.12.2020)

KK3: Hatice ÇALAKAN, 65 yaşında, okur-yazar değil, evli, ev hanımı. (mülakat tarihi: 10.08.2020)

KK4: Leman ŞAHAN, 30 yaşında, üniversite mezunu, evli, öğretmen. (mülakat tarihi: 05.09.2020)

KK5: Meryem SARIGÜL, 61 yaşında, ilkokul mezunu, evli, ev hanımı. (mülakat tarihi: 14.07.2020)

KK6: Zeynep SARIGÜL, 33 yaşında, lise mezunu, evli, ev hanımı. (mülakat tarihi: 13.01.2021)

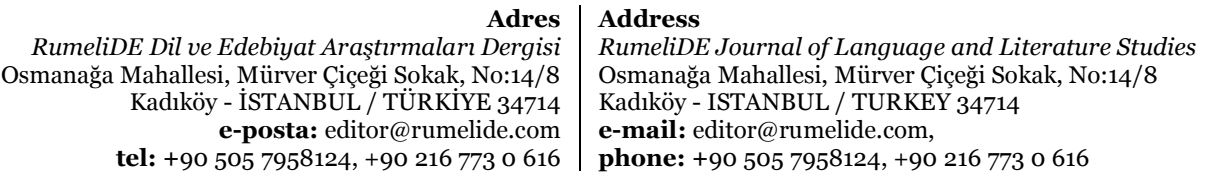

